\title{
Copyrighting God
}

Andrew Ventimiglia. Copyrighting God: Ownership of the Sacred in American Religion. Cambridge: Cambridge University Press, 2019), vii + 247pp. \$115 hardcover; \$34.99 softcover. ISBN: 9781108420518 (hardcover); 9781108430371 (softcover).

Can God own a copyright? How about a divine amanuensis? If so, could a church obtain and wield that legal right for spiritual ends? And, if yes, at what cost to its self-understanding and mission? Copyrighting God explores the intertwining of theological doctrine and intellectual property as churches and courts struggle with the legal protection of religious expression.

Andrew Ventimiglia provides the first major scholarly assessment of the use and cultural effects of intellectual property disputes on religious movements. Ventimiglia is an assistant professor of mass media in the School of Communication at Illinois State University whose research interest concerns "the history and cultural effects of intellectual property law in the United States." The questions at stake in these legal disputes may seem farcical or nonsensical, but Ventimiglia demonstrates that they have had transformative effects on both religious life and legal doctrine. For different reasons, these conflicts make both groups uneasy. Courts resist adjudicating religious conflicts out of deference to the First Amendment. Yet, Ventimiligia demonstrates that lawyers and judges cannot easily put aside their normative sense of religion by carefully avoiding the subject in their opinions. Religious communities distrust secular courts' ability to handle their doctrinal disagreements with appropriate sensitivity. Paul's caution to the church in Corinth, "When you take another believer to court, you have lost the battle already" (1 Corinthians 6:7), resonates beyond Christian circles. Churches must simultaneously make legal arguments that will prevail in court while translating and justifying them in theological terms for their membership, all the while keeping an eye out for how their litigation affects their public perception. No wonder these cases at times backfire in spectacular ways. But, as Ventimiglia shows, these cases have helped substantially to advance our understanding of intellectual property. In that sense, religious organizations have 'punched above their weight' by forcing attention to minority currents flowing through copyright law.

Ventimiglia studies the complex interrelationship between intellectual property and religion through a series of case studies, ranging from Mary Baker Eddy's defense of her authorial rights to Science and Health with Key to the Scriptures in the 19th century to the Church of Scientology's aggressive policing of its copyright and trade secrets during the 20th. These explorations demonstrate that authors and religious organizations have multitudinous motivations when defending religious doctrine with legal arguments.

In the case of The Urantia Book, for example, the Urantia Foundation asserted its copyright over the work to limit its circulation. The leaders of the Urantia Foundation considered that the mystery and message of the book was preserved best when the volume was transmitted by interpersonal encounter, not sold publicly in bookstores or made available in digital format. The foundation ran into trouble when a splinter group wanted to disseminate its text more widely, leading to a copyright dispute about the spiritual custody of divinely-inspired texts.

In other cases, the right of integrity or the right of withdrawal came to the fore. Should prophets be able to prevent others from altering or expurgating their prophetic words? Mary Baker Eddy believed she had a moral obligation to prevent her publications from being adulterated. In that 
sentiment, she drew from biblical example. "I warn everyone who hears the words of the prophecy of this book," wrote the author of the book of Revelation. "If anyone adds to them, God will add to that person the plagues described in this book; if anyone takes away from the words of the book of this prophecy, God will take away that person's share in the tree of life and in the holy city..." (Rev 22:18-19). In the end, federal law could not prevent the issuance of abridged, expanded, or paraphrased versions of either Science and Health or the Bible when they entered the public domain, however offensive such editions may be to certain religious communities.

What happens when a church comes to disown its prophetic message? Does copyright also convey the right not only to cease publishing texts and but also to prevent others, who may continue to believe in those scriptures, from disseminating them as well? A legal conflict about whether Herbert W. Armstrong's Mystery of the Ages (1985) could be suppressed broke out between its copyright holder, a reforming Worldwide Church of God, and the Philadelphia Church of God, which laid claim to Armstrong's spiritual mantle. In the end, the court adjudicated the case as if it were a dispute about the limits of fair use, but Ventimiglia discerns the presence of normative assumptions about religion in the background.

In the United States, the rationale for copyright law is fundamentally economic. The constitutional purpose of copyright law is to motivate artists by providing them with limited and temporary monopolies to market their creations. But a nexus of other ideas surround copyright law, sometimes finding footholds in the law (like the concept of "fair use") and other times persisting primarily in the public mind (as with the author's right to attribution and integrity). In many of the instances Ventimiglia analyzes, these subterranean views of copyright surface uneasily in courtrooms. The underlying connection between censorship and copyright is reflected in the fraught relationship between the "Copyright Clause" (Article I, Section 8, Clause 8) of the Constitution and First Amendment protections for religious belief, speech, and the press.

Ventimiglia's skillful intertwining of biographic detail, historical background, and legal analysis makes Copyrighting God an engaging and instructive read. He writes with sympathy toward movements that often exist on the religious fringe, treating fundamentalists and New Agers with fairness and impartiality. By doing so, he brings novel perspectives to otherwise stale conversations. For instance, he recasts the Scientologists' litigations during the mid-1990s not as a broadside against the Internet in general, but as arising from an alternative vision of responsible, interpersonal networked communication opposed to the freewheeling anarchic society that Stewart Brand encapsulated in his slogan, "information wants to be free."

Copyrighting God will appeal to librarians who work in the field of scholarly communications. While not necessarily sharing the religious convictions, academic authors also resort to copyright for non-market considerations and to achieve distinctive ends. Ventimiglia presupposes his readers have a baseline understanding of the legal system in general and intellectual property law in particular. Contrary to the title of the book, he also touches on trade secret law, trademark law, and even protection of traditional knowledge, assuming that his readers will be sufficiently familiar with these topics to follow his line of argument. For theological librarians, the volume provides valuable theoretical insight into the spectrum of motivations religious authors and denominations have for publishing spiritual literature and, practically, may also help theological archivists to negotiate more sophisticated deeds of gift when acquiring their personal and corporate archives.

Clifford B. Anderson Associate University Librarian for Research and Digital Strategy Vanderbilt University Nashville, TN 